\title{
Paradoxes in Novel Hepatitis C Therapies: Is Combination of Sofosbuvir and Ribavirin Without Interferon Effective in Genotype 16 Chronic HCV Patients?
}

\author{
Yeni Hepatit C Tedavilerindeki Paradokslar: Interferonsuz Sofosbuvir ve Ribavirin Kombinasyonu \\ Genotip 1b Hepatit C Virüsü ile Enfekte Hastalarda Etkili mi?
}

\author{
Ergenekon KARAGÖZ1, Vedat TURHAN1, Asım ÜLÇAY1, Alpaslan TANOĞLU2, Hakan ERDEM1
}

${ }^{1}$ GATA Haydarpaşa Training Hospital, Clinic of Infectious Diseases and Clinical Microbiology, Istanbul, Turkey

2GATA Haydarpaşa Training Hospital, Clinic of Gastroenterology, Istanbul, Turkey

Key Words: Hepatitis C, sofosbuvir, interferon

Anahtar Kelimeler: Hepatit C, sofosbuvir, interferon

\section{Dear Editor,}

Chronic hepatitis $\mathrm{C}$ virus (HCV) infection has become a major and significant public health problem whereas this virus has already infected approximately 170 million people worldwide.

It is assumed that nearly 350.000 patients across the globe have lost their lives due to this infection (1). The prevalence of HCV infections in Turkey was reported to be $0.3-0.7 \%$ (2). As in developing countries, in our country, the prevalence of hepatitis $B$ infections is gradually decreasing thanks to widespread hepatitis B vaccination programs (3). However, HCV infection makes a turn to become a major problem due to the absence of an effective vaccine to avoid HCV and the increase in intravenous drug addiction.

Regarding chronic HCV therapy, regimens based on interferon which was a drug administered alone at a certain term at the beginning of the treatment of chronic HCV infection while this drug is still used as a touchstone in combined therapy has increased sustained virologic response rate over $70 \%$ when administered as triple regimens together with telepravir and boceprevir, drugs which recently entered the market. However, escalated side effects (anemia, neutropenia, rash, sensation of anorectal discomfort and etc.), increased tablet intake and difficulty in decreasing dosage due to problems with resistance have negatively affected therapeutic compliance when these drugs were used together with interferon and ribavirin, opened the door for investigators to seek new and different therapies (4). Within this context, antiviral agents that may provide a chance for cure in more patients and with a lesser degree of side effect profile and a direct effect in the treatment of $\mathrm{HCV}$ infections were reproduced. Sofosbuvir is a novel drug emerged as the first nucleotide polymerase inhibitor, with a pan-genotypic efficacy and high resistance barrier and has been studied as triple therapy with interferon and ribavirin in chronic hepatitis $\mathrm{C}$ patients who have not received any therapy before. This new combination raised our hopes as it provided more than $90 \%$ sustained virologic response rate in all type of genotype-induced infections. On the other hand, sofosbuvir played a key role in pioneering interferon-free therapeutic regimens in patients who are capable of tolerating interferon and where this drug cannot be administered.

Studies demonstrated that the dual combination of sofosbuvir and ribavirin provided sustained virologic responses over $80 \%$ in entire genotypes and, consequently, these regimens found their place in the therapeutic guidelines of

Address for Correspondence: Ergenekon Karagöz MD, GATA Haydarpașa Training Hospital, Clinic of Infectious Diseases and Clinical Microbiology, Istanbul, Turkey 
Europe and USA $(5,6)$. However, in multiple studies carried out in our country related to genotype distribution it has been demonstrated that genotype $1 \mathrm{~b}$ was the most frequently seen genotype in patients infected with HCV (7). Accordingly, the most major and significant point in our country is the recognition of the activity of sofosbuvir in genotype $1 \mathrm{~b}$ group patients and this activity is well-known.

In recent studies, it was shown that a triple regimen of interferon, ribavirin and sofosbuvir provided $82 \%$ sustained virological response in gynotype $1 \mathrm{~b}$ hepatitis $\mathrm{C}$ patients who have not received any therapy before. However, in genotype $1 \mathrm{~b}$ group of patients where interferon was not tolerated or interferon cannot be administered, combined therapy with sofosbuvir and ribavirin provided only a rate of $53 \%$ sustained virological response $(8,9)$. Accordingly, sofosbuvir and ribavirin therapy administered to genotype $1 \mathrm{~b}$ patients without interferon is not assumed to be a good combination to obtain a sustained virologic response (5). The American Association for the Study of Liver Diseases (AASLD) guideline recommends that the addition of simeprevir to this therapeutic regimen (sofosbuvir and ribavirin) in genotype 1 patients can provide higher sustained virologic response in difficult-to-cure chronic HCV patients (6).

More recently, together with a combination of sofosbuvir $400 \mathrm{mg}$ and ledipasvir $90 \mathrm{mg}$, the dual regimen of sofosbuvir $400 \mathrm{mg}$ and daclatasvir $60 \mathrm{mg}$ has raised up as a more effective combination and is featured as the best therapies with sustained virologic response rate over 95\% among interferonfree regimens $(10,11,12,13)$.

Another study carried out by Manns et al. (14) showed that daclatasvir and asunaprevir dual therapy provided sustained virologic response more than $90 \%$ in treatment-naïve genotype $1 \mathrm{~b}$ patients; and more than $82 \%$ sustained virologic response in genotype $1 \mathrm{~b}$ patients who failed to tolerate interferon and respond to classical therapy previously. A recent study has demonstrated that ritonavir boosted ABT-450 (ABT450/r), ombitasvir, and dasabuvir therapy achieves $97 \%$ and $100 \%$ sustained virologic response with or without ribavirin in treatment-experienced patients with HCV genotype $1 \mathrm{~b}$ infection (15). In another study, twelve weeks of treatment with ABT-450/r, ombitasvir and dasabuvir without ribavirin was found to be highly effective among previously untreated genotype 1 patients with $98 \%$ sustained virologic response (16). All these studies indicate that these therapies seem to become the standard of care for hepatitis $C$ genotype 1 infection.

As a result, interferon-free therapeutical regimens is a reality in today's medical world, but not a dream anymore. As it is in classical therapies, especially considering the genotype of the patient, it is very important to personalize therapy for such patients and initiate an appropriate therapeutic regimen for the most convenient patient after taking notice of prognostic markers which may affect the response to the therapy. However, it should not be forgotten that, if interferon intolerance is present in genotype $1 \mathrm{~b}$ chronic hepatitis $\mathrm{C}$ patients, then it is possible to obtain better and more effective results from therapies such as therapeutic regimens of ledipasvir/sofosbuvir (with or without ribavirin), sofosbuvir plus simeprevir (with or without ribavirin), sofosbuvir plus daclatasvir or by a dual regimen of daclatasvir and asunepravir than that from sofosbuvir plus ribavirin.

Concept: Ergenekon Karagöz, Vedat Turhan, Hakan Erdem, Design: Ergenekon Karagöz, Alpaslan Tanoğlu, Asım Ülçay, Vedat Turhan, Data Collection or Processing: Ergenekon Karagöz, Analysis or Interpretation: Ergenekon Karagöz, Hakan Erdem, Literature Search: Ergenekon Karagöz, Writing: Ergenekon Karagöz, Peer-review: External and Internal peer-reviewed, Conflict of Interest: No conflict of interest was declared by the authors., Financial Disclosure: The authors declared that this study has received no financial support.

\section{References}

1. Ormeci N, Erdem H. Basic answers to complicated questions for the course of chronic hepatitis $\mathrm{C}$ treatment. Expert Rev Gastroenterol Hepatol. 2012; 6:371-382.

2. Erdem $H$, Akova M. Leading infectious diseases problems in Turkey. Clin Microbiol Infect. 2012;18:1056-1067.

3. Tosun S, Deveci S, Kaplan Y, Kasirga E. Should a booster dose be administered in children after mass immunization for hepatitis B? Hepat Mon. 2011; 11:440-444.

4. Liang TJ, Ghany MG. Current and future therapies for hepatitis C virus infection. N Engl J Med. 2013; 368:1907-1917.

5. European Association for Study of Liver. EASL Clinical Practice Guidelines: management of hepatitis C virus infection. J Hepatol. 2014; 60:392-420.

6. Rapposelli D. Highlights from the Annual Meeting of the AASLD. Gastroenterol Hepatol (N Y). 2014; 10:194-195.

7. Kabakçı Alagöz G, Karataylı SC, Karataylı E, Celik E, Keskin O, Dinç B, Cınar K, Idilman R, Yurdaydın C, Bozdayı AM. Hepatitis $C$ virus genotype distribution in Turkey remains unchanged after a decade: performance of phylogenetic analysis of the NS5B, E1, and 5'UTR regions in genotyping efficiency. Turk J Gastroenterol. 2014; 25:405-410.

8. Sulkowski MS, Naggie S, Lalezari J, Fessel WJ, Mounzer K, Shuhart M, Luetkemeyer AF, Asmuth D, Gaggar A, Ni L,Svarovskaia E, Brainard DM, Symonds WT, Subramanian GM, McHutchison JG, Rodriguez-Torres M, Dieterich D; PHOTON-1 Investigators. Sofosbuvir and ribavirin for hepatitis $C$ in patients with HIV coinfection. JAMA. 2014; 312:353-361.

9. Lalezari JP, Nelson DR, Robert H. Once daily sofosbuvir plus ribavirin given for 12 or 24 weeks in treatment naïve patients with HCV infection:The Quantum Study. EASL 48th Annual Meeting, The Netherlands, Amsterdam 2013.

10. Lawitz E, Poordad F, Brainard DM, Hyland RH, An D, Dvory-Sobol $\mathrm{H}$, Symonds WT, McHutchison JG, Membreno FE. Sofosbuvir with peginterferon-ribavirin for 12 weeks in previously treated patients with hepatitis C genotype 2 or 3 and cirrhosis. Hepatology. 2015; 61:769-775.

11. Lawitz E, Sulkowski MS, Ghalib R, Rodriguez-Torres M, Younossi ZM, Corregidor A, DeJesus E, Pearlman B, Rabinovitz M, Gitlin N, Lim JK, Pockros PJ, Scott JD, Fevery B, Lambrecht T, Ouwerkerk-Mahadevan S, Callewaert K, Symonds WT, Picchio G, Lindsay KL, Beumont M, Jacobson IM. Simeprevir plus sofosbuvir, with or without ribavirin, to treat chronic infection with hepatitis $C$ virus genotype 1 in non-responders to pegylated interferon and ribavirin and treatment-naive patients: the COSMOS randomised study. Lancet. 2014; 384:1756-1765.

12. Afdhal N, Reddy KR, Nelson DR, Lawitz E, Gordon SC, Schiff E, Nahass R, Ghalib R, Gitlin N, Herring R, Lalezari J, Younes 
ZH,Pockros PJ, Di Bisceglie AM, Arora S, Subramanian GM, Zhu Y, Dvory-Sobol H, Yang JC, Pang PS, Symonds WT, McHutchison JG, Muir AJ, Sulkowski M, Kwo P; ION-2 Investigators. Ledipasvir and sofosbuvir for previously treated HCV genotype 1 infection. N Engl J Med. 2014; 370:1483-1493.

13. Sulkowski MS, Jacobson IM, Nelson DR. Daclatasvir plus sofosbuvir for HCV infection. N Engl J Med. 2014;370:15601561.

14. Manns M, Pol S, Jacobson IM, Marcellin P, Gordon SC, Peng CY, Chang TT, Everson GT, Heo J, Gerken G, Yoffe B,Towner WJ, Bourliere M, Metivier S, Chu CJ, Sievert W, Bronowicki JP, Thabut D, Lee YJ, Kao JH, McPhee F,Kopit J, Mendez P, Linaberry $M$, Hughes E, Noviello S; HALLMARK-DUAL Study Team. All-oral daclatasvir plus asunaprevir for hepatitis $C$ virus genotype 1b: a multinational, phase 3, multicohort study. Lancet. 2014; 384:1597-1605.
15. Andreone $P$, Colombo MG, Enejosa JV, Koksal I, Ferenci $P$, Maieron A, Müllhaupt B, Horsmans $Y$, Weiland $O$, Reesink HW, Rodrigues L Jr, Hu YB, Podsadecki T, Bernstein B. ABT450, ritonavir, ombitasvir, and dasabuvir achieves $97 \%$ and $100 \%$ sustained virologic response with or without ribavirin in treatment-experienced patients with HCV genotype $1 \mathrm{~b}$ infection. Gastroenterology. 2014; 147:359-365.

16. Ferenci $P$, Bernstein D, Lalezari J, Cohen D, Luo $Y$, Cooper C, Tam E, Marinho RT, Tsai N, Nyberg A, Box TD, Younes Z, Enayati P,Green S, Baruch Y, Bhandari BR, Caruntu FA, Sepe T, Chulanov V, Janczewska E, Rizzardini G, Gervain J, Planas R, Moreno C,Hassanein T, Xie W, King M, Podsadecki T, Reddy KR; PEARL-III Study; PEARL-IV Study. ABT-450/r-ombitasvir and dasabuvir with or without ribavirin for HCV. N Engl J Med. 2014; 370:1983-1992. 